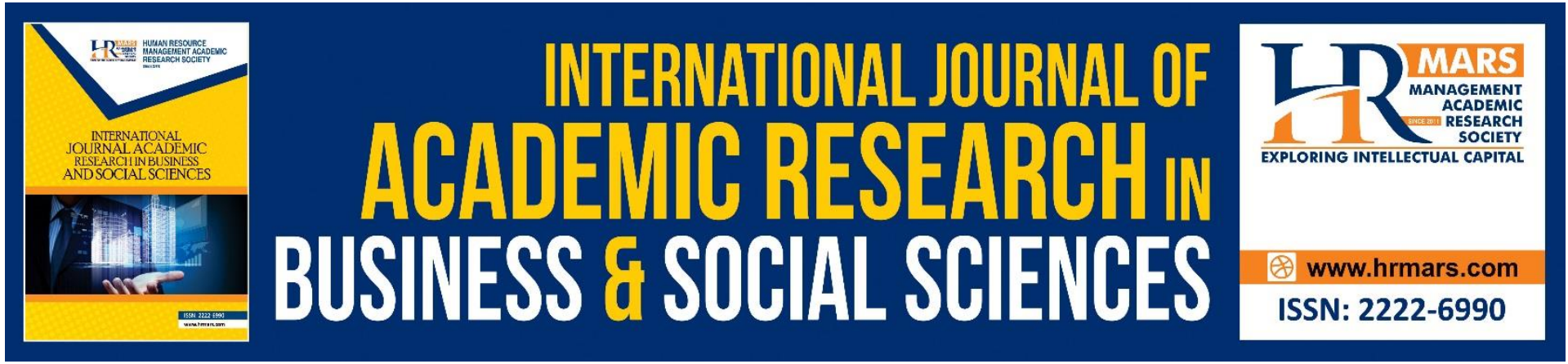

\title{
Exploring the Compliance Behaviour During COVID-19 Pandemic from Social Psychology Perspectives
}

Abdul Rashid Abdul Aziz, Zuraina Ali, Najihah Mohd Noor \& Shahirah Sulaiman

To Link this Article: http://dx.doi.org/10.6007/IJARBSS/v11-i7/10493

DOI:10.6007/IJARBSS/v11-i7/10493

Received: 19 May 2021, Revised: 20 June 2021, Accepted: 04 July 2021

Published Online: 24 July 2021

In-Text Citation: (Aziz et al., 2021)

To Cite this Article: Aziz, A. R. A., Ali, Z., Noor, N. M., \& Sulaiman, S. (2021). Exploring the Compliance Behaviour During COVID-19 Pandemic from Social Psychology Perspectives. International Journal of Academic Research in Business and Social Sciences, 11(7), 561-578.

Copyright: (C) 2021 The Author(s)

Published by Human Resource Management Academic Research Society (www.hrmars.com)

This article is published under the Creative Commons Attribution (CC BY 4.0) license. Anyone may reproduce, distribute, translate and create derivative works of this article (for both commercial and non-commercial purposes), subject to full attribution to the original publication and authors. The full terms of this license may be seen at: http://creativecommons.org/licences/by/4.0/legalcode

Vol. 11, No. 7, 2021, Pg. 561 - 578

Full Terms \& Conditions of access and use can be found at http://hrmars.com/index.php/pages/detail/publication-ethics 


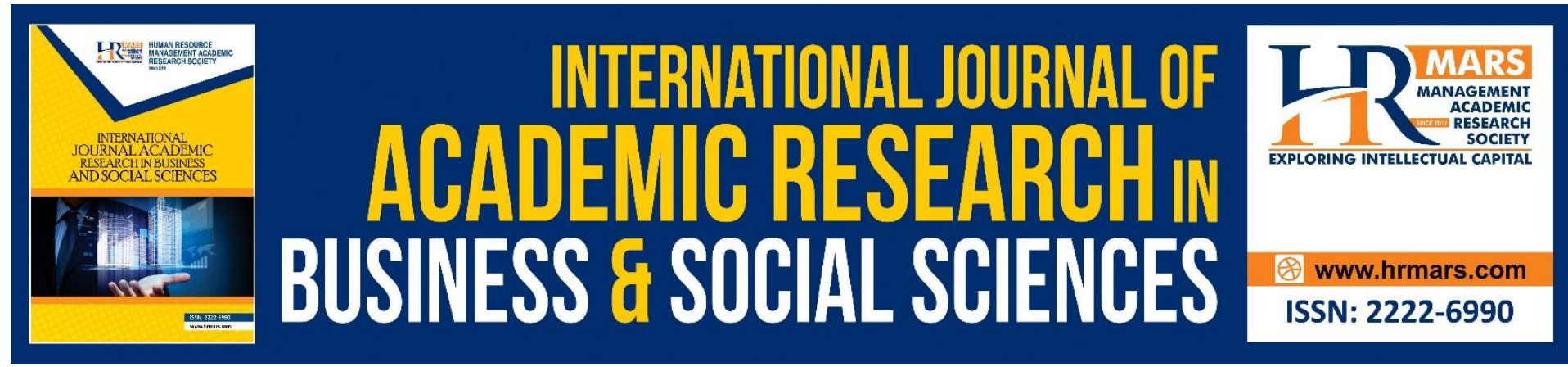

\title{
Exploring the Compliance Behaviour During COVID-19 Pandemic from Social Psychology Perspectives
}

\author{
Abdul Rashid Abdul Aziz ${ }^{1}$, Zuraina Ali², Najihah Mohd Noor ${ }^{3}$ \& \\ Shahirah Sulaiman ${ }^{4}$ \\ ${ }^{1,3,4}$ Faculty of Leadership and Management, Universiti Sains Islam Malaysia, ${ }^{2}$ Centre of \\ Modern Language, Universiti Malaysia Pahang, Malaysia
}

\begin{abstract}
The study explores on the compliance behaviour of Malaysians during the pandemic of COVID-19 from the social psychology perspectives. Most of the research materials referred in this study are from secondary resources which are from research articles, newspaper articles, materials from magazines and bulletin. Then, content analysis was employed to obtain relevant themes for the study. Five themes are identified namely, (i) social norms during the COVID-19 outbreak, (ii) compliance with new norms through social restrictions, (iii) social conformity to adhere to new norms, (iv) optimistic bias during new norms and (v) diffusion of responsibilities during new norms. The implication of the study showed that there are varies compliance and non-compliance behaviours that are demonstrated by fellow Malaysians as the pandemic shows no signs of slowing down. It is therefore vital for Malaysians to follow the appropriate Standard Operation Procedures and be vigilant and resilient in facing this pandemic.
\end{abstract}

Keywords: COVID-19 Outbreak, Compliance Behaviour, Social Psychology, Pandemic, New Norms

\section{Introduction}

The spread of COVID-19 pandemic is a global unprecedented, alarming phenomenon. It has first affected Malaysia on January 25, 2020 (Sipalan \& Holmes, 2020), when eight Chinese nationals were put under quarantined at a hotel in Johor Bahru after they had close contact with an infected person in Singapore (Loh, 2020). Although the initial reports found that the screening test conducted was negative, three of them were confirmed positive and later quarantined at Sungai Buloh Hospital. Meanwhile, in early February 2020, there was an increase of COVID-19 infection cases in Sabah and Sarawak due to some tourist from China went to the state. Also, on February 4, Malaysia reported two new cases, including a local man as the first case of Malaysians (Bernama, 2020). Then, it is seen that the number of cases keeps rising in Peninsular Malaysia until March 2020. Especially, at least 5,000 locals were believed to have been exposed to COVID-19 in a religious event in Kuala Lumpur, which is the Jemaah Tabligh gathering from local and international attendees at Masjid Jamek Sri Petaling at the time (Reuters, 2020). As a result, Malaysia has announced a full restriction on 
monitoring foreign nationals particularly those who are from high-infected cases countries as China, Italy, Iran and South Korea starting from March 13, 2020. The drastic spread and number of cases that keeps expanding have urged Government of Malaysia to enforce Movement Control Order (MCO) on March 18, 2020 to curb this epidemic (Sukumaran, 2020). This shows that the Government of Malaysia is fully aware and concern in taking over COVID19 as teams from the Ministry of Health Malaysia, the Ministry of Defence, the Ministry of Domestic Trade and Consumer Affairs, several agencies and other ministries have participated accordingly with various initiatives and campaigns.

It is imperative to rein in the chain of COVID-19 spread especially through the transmission through humans (close contact, touch, surrounding, air, cleanliness, etc) as because there are still no drugs or vaccines that can cure patients from the infection. It occurs from close contact with patients or individuals who have been infected with the COVID-19 pandemic. Close contact means the individual is with the person or people (family member, colleague or any individual who has been infected with COVID-19) for a minimum of 20 minutes in a covered area (supermarkets, government offices or clinics) without wearing any mask or personal protective equipment (PPE). The spread can be transmitted through three conditions, as follows:

1. Through the distribution of particles into the air where the virus can be spread through the splash of particles from the respiratory system such as coughing and sneezing (Fazilah, 2020). 2. Through touch that is when the individual touches the surface or object that has been contaminated with the virus, and then the individual touches their mouth, nose and eyes. It also can be transmitted if a person shakes their hands and hugs with the infected person.

3. Through "sporadically" which refers to no specific sources of spread by the infections occurred. It refers to when a person who is not or never be with any close contact of COVID19 patient, but he or she has been confirmed positive. This sporadic infection can be caused by other factors and possibilities.

\section{Problem Statement}

COVID-19 pandemic has created a global concern that its rapid spread has left more than 42 million people worldwide infected with the latest statistics released by the World Health Organization (WHO) on $25^{\text {th }}$ October 2020. In fact, this number is expected to increase. Surprisingly, until now there is still no vaccine that has been successfully produced and even the cause of its existence is still a mystery. The first case of local infection was reported on February 5 (Amir, 2020). The number of cases keeps increasing and the Government of Malaysia has taken proactive steps by implementing the Movement Control Order (MCO) nationwide starting March 18, 2020 (Rashid, 2020). Therefore, the government urges their people to learn and enliven a new norm by creating a Standard Operating Procedure or SOP, which is essential to stop the spread of the COVID-19 spreads The SOPs are wearing face masks, keep social distancing, avoiding being in crowded places, washing hands frequently with soap, avoiding handshakes, sanitizes their hands or objects that they touch as well as avoiding touching face and nose.

In addition, the country is currently entering the phase of the Rehabilitation Movement Control Order (RMCO) starting June 10, 2020, after a new case of COVID-19 positive infection has decreased. However, it seems that every day there are still new clusters 
discovered and it is reported that 50 per cent of individuals who return from abroad do not comply with the order of self-quarantined (Isma \& Raja, 2020). It can be avoided if they adhere to the Standard Operating Procedures (SOP) and MCO implemented. Unfortunately, some are still ignorant and do not give any commitment accordingly. For instance, one of the clusters identified which is Sivagangga cluster, caused by the non-compliance restaurant owner in Kedah who arrived from abroad and simply runs the restaurant as escaped from being quarantined. Many are infected and has spread to three other states which are Kedah, Perlis and Penang (Hifzuddin, 2020). According to Ministry of Health (2020), the Tawar and Sivagangga Clusters have spread more dangerous infections which is a mutation virus type D614G. Thus, individual who are non-compliance with the SOP will cause many people to bear the consequences.

Such behaviour of non-compliance to SOP and MCO implementation as travel interstate, not wearing face masks as well as not quarantined accordingly after returning from abroad will spread the virus and endanger the lives of others. Some are very selfish and ignorant that they even bring their children under two years old along to public places, even though this age of group is advised not to be taken to public places and are at risk of infection. According to Ministry of Security \& Defence, those who found violated the rules under the Prevention and Control of Infectious Diseases Act 1988 (Act 342), can be fined a maximum of $\mathrm{RM} 1,000$ or six months imprisonment, or even both, if convicted (Bernama, 2020). Still there are people disobeyed SOP, MCO and underestimated the deadly threat of COVID-19. It is discovered that more than 14,000 individuals have committed offenses in violation of the MCO when it was implemented on March 18 to April 14 for phases 1 and 2. Minda Rakyat (2020) reported that Bukit Aman Criminal Investigation Department (CID) director, claimed there was an increased number of arrests to 11,295 cases during second phase of MCO as compared to 3,627 cases during first phase of MCO. The increment was due to the actions of individuals who disobeyed the MCO instructions to stay at home. Some of the individuals were inspected and detained while hanging out in coffee shops, public gathering, public crowded places, and even disobey MCO roadblocks.

This depicts that there are still people as an individual or as part of a community who fail to understand the importance of adhering such impose. Therefore, the study attempts to explain the non-compliance of SOP from a social psychology perspective through an explanation of social norms, the phenomenon of social conformity, optimism bias, diffusion of responsibility, suggestions and solutions to overcome the issues.

\section{Behaviour Compliance}

The definition of obedience derives from the word obedience, following orders, rules, and laws obediently - or simply define does not object. While compliance refers to the nature of obeying and obeying certain rules and things that have been set (Dictionary of Dewan Bahasa dan Pustaka, 2020). A person's value of compliance means a personal responsibility and commitment which manifested by law-abiding behaviour (Tyler 2006; Robinson \& Darley 2004). It can therefore be concluded that obedient behaviour refers to the form of human action that can be seen in accordance with certain rules, laws, or policies, as well as in accordance with the study of social psychology which generally looks at social situations, exploration of elements of social thoughts, feelings and behaviours humans (Kruglanski \& Stroebe, 2011). 
Bottoms (2001) states that basically, there are several factors contribute to an individual's compliance with the law. Compliance is related to the behaviour and orientation of individual habits (Jonathan et al., 2012). If an individual obeys the law because of the values that they embrace, then it is unlikely that the individual violated the law even though the situation at the time provided an opportunity for the individual to do so (Robinson and McNeill 2008). Factors such as genetics, psychology, environment, government policy and values in society influence individual compliance.

In addition, to see the behaviour of individuals in complying with or disobeying these new norms, the phenomenon according to the perspective of social psychology needs to be explained. The behaviour compliance of new norm includes social norms, social conformity, optimism bias and diffusion of responsibility that led to SOP compliance behaviour during the new norms, Figure 1 shows the social psychology elements that impact compliance behaviour during new norms.

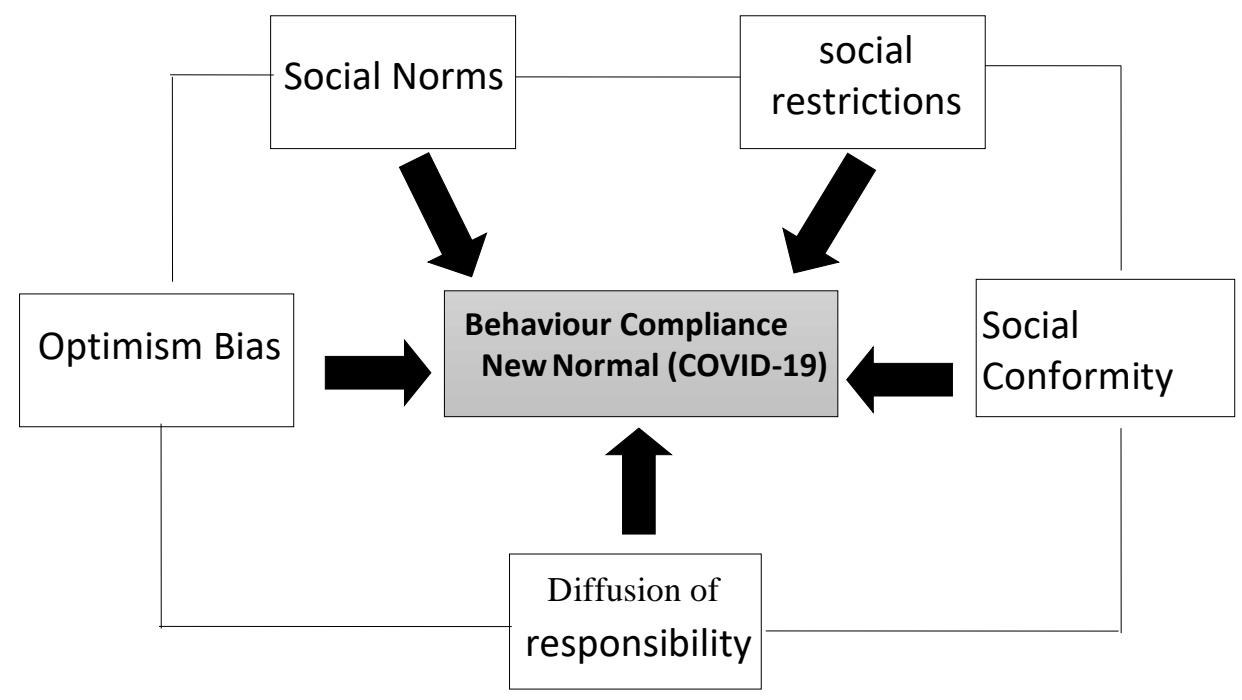

Figure 1: Behaviour Compliance Factors based on Social Psychology Elements

Meanwhile, Figure 2 shows the modelling graph and prediction in Malaysia based on the compliance behaviour towards the current SOP during the new norm. The blue skewed indicates that starting from the first Movement Control Order (MCO1) there was an increase in the cases of the pandemic. However, the trend declined during MCO 2, MCO 3 and MCO 4 as Malaysians felt relief due to they were able to comply to the new norms behaviour at the beginning of April until the first of week of May 2020. Cases could have been increased if Malaysians did not comply to the new norms that has been imposed by the Ministry of Health Malaysia. 


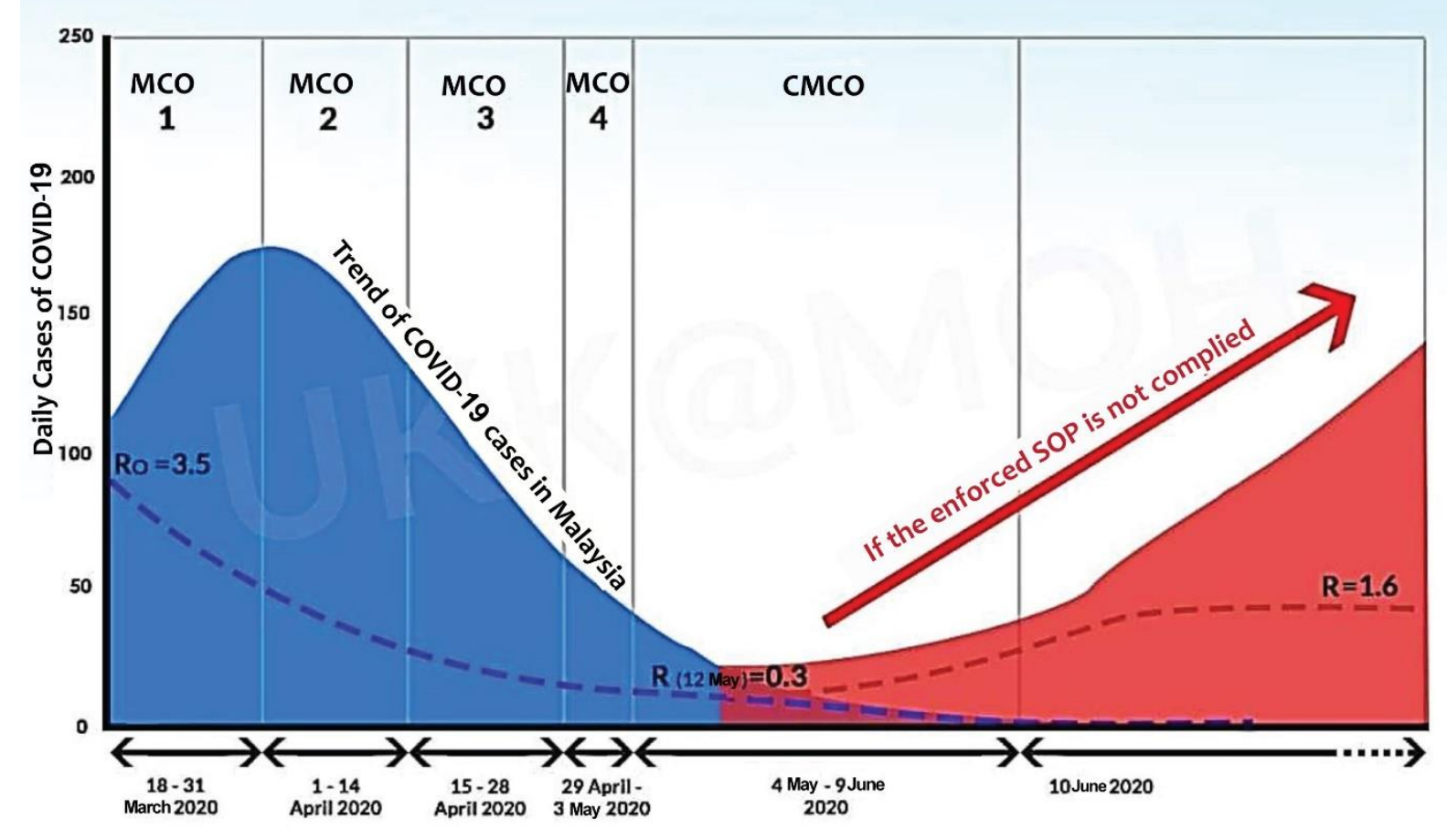

Figure 2: COVID-19 Modeling Graph and Prediction in Malaysia based on Compliance Behavior towards the current SOP during the New Norm. (National Institutes of Health, Ministry of Health Malaysia, 2020)

\section{Methodology}

Generally, the study employs library research study as the design of the current study in that secondary information related to the COVID-19 outbreak is sought to explore the compliance behaviour in relation to social psychology point of view. The information obtained is from various sources such as books, journals, and magazines. This information is collected, filtered and analysed using content analysis techniques. Figure 3 shows the content analysis technique in the current study:

Step One: Preparing a theoretical background for the study conducted.

In employing content analysis method, the authors start by providing a background or explaining the research theory. This means that the authors need to know the aspects to be studied by focusing on relevant issue for the topic that is being discussed. This is done by reading, analysing and structuring relevant content according to the topic of literature review when referring to materials/resources that will be used in reporting on the study conducted.

Step Two: Creating a link between existing research and research proposals.

In this step, the authors need to find a correlation between the proposed study or the topic of literature review with the research that has been done. Links also should be made to the secondary sources obtained from newspapers, magazines and bulletins.

Step Three: Integrating research results into the existing knowledge.

The step requires the authors to integrate the results of the study that is the content that has been linked to be blended with the knowledge of the author himself. This task requires the authors to be analytical and critical before performing the final process where they need to 
write a full report by combining the referenced materials as well as their existing knowledge. Figure 3 shows the procedures of conducting literature review employing content analysis.

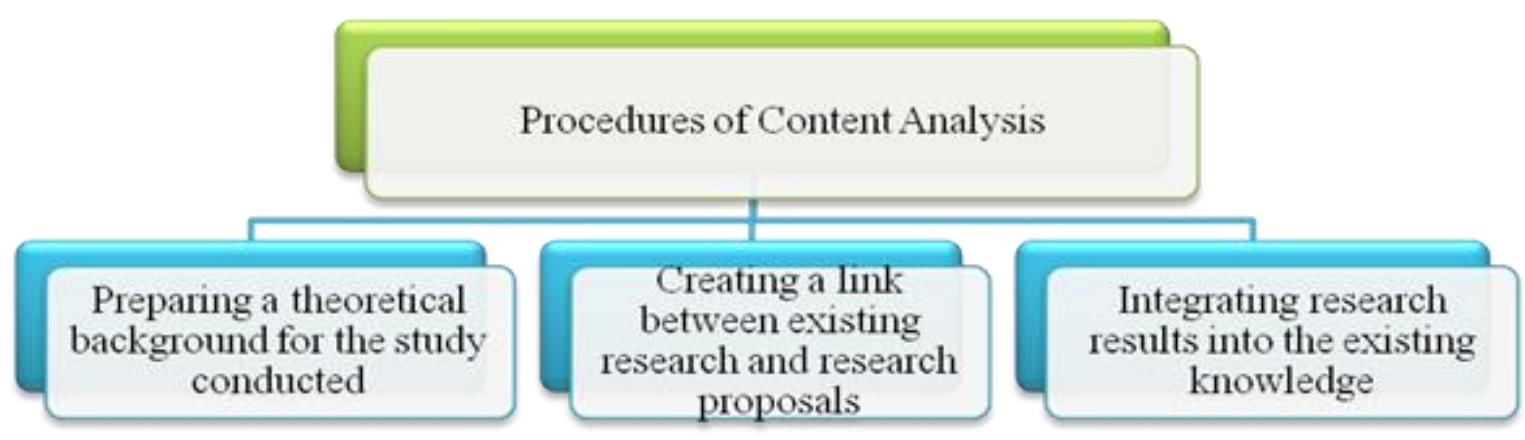

Figure 3: Procedures of conducting literature review employing content analysis (Rashidi, Begum, Mokhtar \& Pereira (2014)

\section{Results and Discussion}

Social norms during the COVID-19 outbreak

Social norms are habits or behaviours that an individual should perform according to his society whether in terms of culture, values, traditions, and customs (Sherif, 1936). In addition, social norms are also the expectations that is set by a group regarding the behaviour that its members should perform (McDonald \& Crandall, 2015). For example, social norms of the community are shake hands and hug each other when meeting with someone, as communication between members within a group (Kincaid, 2004). Meanwhile, from the view of social psychology, the norm is said to be a mental representation of appropriate behaviour and able to control individual's behaviour (Aarts \& Dijksterhuis, 2003). For instance, individuals will not spontaneously make noise in the library because it is customary that the library is a quiet place. Norms are also divided into two namely, the injunctive norm and the descriptive norm. Injunctive norms are beliefs about what should be done, while descriptive norms are beliefs about what others in the group are doing (Cialdini, Reno \& Kallren, 1990). For example, when individuals believe that everyone should comply with the SOP during the new COVID-19 pandemic norm (refer as injunctive norm) but at the same time they also believe that many people do not adhere to the SOP (descriptive norm). These injunctive and descriptive norms can be seen from the point of view of individualism as well as collectivism (Lapinski \& Rimal, 2005). 
Table 1: Types of norms and their levels

\begin{tabular}{|l|l|l|}
\hline Types of Norms & Injunctive norms & Descriptive norms \\
\hline Individual & $\begin{array}{l}\text { Individual perceptions of } \\
\text { pressure to conform to } \\
\text { behaviour. }\end{array}$ & $\begin{array}{l}\text { Individual perceptions of the } \\
\text { prevalence of certain } \\
\text { occurring behaviours }\end{array}$ \\
\hline Collective & $\begin{array}{l}\text { Information obtained } \\
\text { through police is formulated } \\
\text { by specific communities to } \\
\text { promote or prohibit } \\
\text { behaviour. }\end{array}$ & $\begin{array}{l}\text { Information obtained } \\
\text { through observations is } \\
\text { made on the media that } \\
\text { gives an overview of } \\
\text { environmental trends on } \\
\text { specific issues. }\end{array}$ \\
\hline
\end{tabular}

Norms can be demonstrated formally or informally. However, it is certainly difficult to break the norms that have long been formed in society. Imagine our habits all this time that need to be changed immediately - surely it causes discomfort. This is where individuals will make self-adjustments and adaptations. But in the process, there are definitely individuals who have difficulties and this causes the occurrence of behaviour that does not comply with the SOP. Mental health climate can affect the way a person thinks, behaves and feels, where the level of mental well-being will determine the way, a person makes decisions and choices in life, solves problems as well as interacts with others (Rashid et al., 2020). In this challenging outbreak, the changes in social norms are seen to provide solutions in maintaining social order. Yet, it requires cooperation (Bicchieri et al, 2018). Cooperation in complying to social norms is often easier to form in a close-knit group (Alexander, 2005). This is due to the ongoing interactions among the small groups (Bicchieri et al, 2018 quoted from Hardin, 1982). Therefore, to form cooperation in complying with SOP behaviour, focus can be given to small groups such as those who are at villages and residential areas. Authorities need to take the initiative to patrol areas that are under their responsibility to ensure the compliance among the residents on the SOPs imposed of the new norms.

\section{Compliance with New Norms through Social Restrictions}

Norms are often associated with social restrictions. Social restriction is the acceptance of constraint form of response to a behaviour. Social restrictions can be divided into two, formal and informal. Informal social barriers are like discriminating against individuals from groups. Meanwhile, formal social restrictions are fines imposed by a party. For example, the situation in Malaysia starting August 1, 2020, where the government has imposed a fine of RM1000 for anyone who does not wear face mask when in public places and public transport. Although penalties have been imposed, there are still individuals who do not wear face masks. The reality is that many individuals still fail to comply with the SOP even after fines and penalties are carried out. Sadly, the Ministry of Health Malaysia is submitting a proposal to increase the fine rate for compound offenses in accordance with Act 342 (Prevention and Control of Infectious Diseases Act 1988) from the current rate of RM1,000 to RM10,000 (Idris, 2020). 
Although the proposal to increase the fine has many negative feedbacks, it can be the best alternative in increasing individual compliance to the SOP imposed. According to Fehr \& Fischbacher (2004) social restrictions are essential in the enforcement of new norms. For example, Vietnam which was reported to have been free of COVID-19 infection for almost 100 days due to social restrictions in the form of rigid and stricter fines for every offense committed. For example, a fine of thousands of ringgits (10 Million Vietnamese Dong) is imposed on individuals who fail to comply with the quarantine order. Vietnam successfully achieved zero COVID-19 for 100 days fine should be taken consideration.

In addition, social restrictions can also be positive such as in giving compliments, prizes, bonuses or promotions. Among the ways that can be done in providing positive social restrictions is through smiling and thanking to the individuals around. Saying 'thank you for your compliance with the SOP' mean for the individual who adheres to it and those behaviours tend to be reinforced in the future because they feel their efforts are appreciated. This method is one example of positive reinforcement introduced by behaviourism psychologist B.F Skinner. Positive reinforcement is when the occurrence of a behaviour is followed by an increase result in behavioural reinforcement (Miltenberger, 2012). For example, during the new norm, individuals who wear face masks should be complimented and thanked. Thus, individuals tend to repeat the behaviour of wearing face masks.

In addition, authority should place security personnel among Malaysians to ensure they comply to the SOP enforced. Therefore, every responsible individual and citizen should play a role as a police or spy around them. Perhaps, this requires them to report all SOP noncompliant behaviour to the authorities along with evidence such as pictures or videos. For example, the issue of 'the pink bracelet aunty' that spread on the social media due to not quarantining herself, when later was fined RM 8000 and jailed for a day (Balqis, 2020).

\section{Social Conformity to adhere to New Norms}

Social conformity refers to the action of a person to change his behaviour to adjust the response of others (Cialdini \& Goldstein, 2003). There are three types of conformity according to psychologist Herbert Kelman (1958) namely, compliance, identification, and internalization. Compliance is a general conformity, where it is done by the individual only to gain the acceptance of others and due to fear of rejection without changing the original beliefs of the individual. For example, queuing and waiting for a turn when making a payment and greeting when meeting people. Identification, on the other hand, is conformity to someone who is influential on individuals such as leaders or celebrities. Meanwhile, internalizations is the acceptance of a particular belief and behaviour in line with changing the original beliefs of the individual. It is said to be the highest level of conformity. The phenomenon of conformity can also be divided into two forms that can be seen in human social behaviour which are informational social influence and normative social influence.

Informational social influence is known as a social proof which refers to a change of opinion or behaviour is high that when an individual agrees with the person, they believe has the right information (Cialdini, 2009). Cialdini (2009) further explains that humans believe the probability of committing a wrong action is low when they follow the actions of those around them. Clearly, this phenomenon often occurs when individuals experience ambiguity in the situations they face, they often tend to follow the actions of those around them. Kelman 
(1958) stated that this type of conformity can produce high compliance and can even be personal acceptance to individuals (internalization).

In such unfortunate pandemic, diverse societal backgrounds allow this phenomenon to occur. For example, groups with a background in medicine and science understand it better of why it is vital to adapt new norms such as wearing face masks and contact avoidance because they are more aware of how the virus spreads than those who have not studied it. On the other hand, individuals who do not have accurate information about COVID-19 will mimic the behaviour of those around them. If the majority of them do not practice social distancing or do not wear face masks, then individuals feel it is not an offense since most people observe the same behaviour. This is supported by studies that find that social proof is the result of social comparisons involving the individual opinions with others to produce an accurate validity assessment of an opinion or behaviour (Festinger, Schachter \& Back, 1950; Hardin \& Higgins, 1996; Turner, 1991). Social proof is also found to be more likely to occur in communities that are collective rather than individual (Bond \& Smith, 1996).

Normative social influence, on the other hand, is the harmony that results when an individual conducts behaviour to accept and avoid isolation and rejection by others (Aronson, Wilson, Akert, 2005). Thus, individuals will usually conform to social norms. For example, if everyone shows behaviour that obeys specific rules, then others will also follow the latter. This proves that individual behaviour is influenced by the group regardless of whether the individual is right or wrong.

Conformity in the informational social influence that can be done to curb social proof in an undesirable situation is to provide accurate and effective information to the community regarding the way COVID-19 pandemic being spread. It is also important to comply with the SOP during the new norms. When individuals understand and believe that by following SOPcompliant behaviours they can avoid being infected and will do so willingly (Clark, Davila, Regis \& Kraus, 2020). This information can be conveyed by specific individuals depending on the target age, for example, advertisements of new norm SOP practices by cartoon characters such as Didi \& Friends and Boboi Boy to influence children. Meanwhile, examples of SOP practices that attract the interest of adults can be done by influential individuals such as celebrities or leaders to affect the group at that age. According to Cialdini (2001) individuals are usually concerned with the influence of peers which they are more easily influenced than those who have generational differences from them. Thus, individuals will perform similar actions with people they feel have a connection or similarity with them.

Moreover, the conformity of the social normative influence in complying with the SOP during the new norms is seen to be different. This is due to the type of conformity appears to be guided by the surrounding norms then it can happen in a positive or negative way. For instance, media can make changes by reporting and showing more examples of SOPcompliant behaviour than vice versa. In this way, the community can see more people complying with the SOP than those who do not. In addition, among the solutions that can be done is to increase the normative message urging 'us' (togetherness values) as a team in fighting this epidemic. This normative message in its most straightforward language is the 'voice of the masses' or the majority of the society doing it. An example of a normative message that can be done is a comparison of the percentage of SOP compliance in one 
neighbourhood with another neighbourhood. Based on previous studies, it is found that this normative message is able to improve pro-social behaviour such as following the rules and adherence to proper social behaviour. One of the studies that has been conducted is about saving energy supply with the use of different messages. The group that received the normative message that is the comparison of electricity consumption between neighbours was found to save more electricity consumption than those who received the non-normative message in the form of telephone calls to save electricity with the purpose of saving money and energy consumption (Brandon et al., 2018). Similar findings were obtained in the study of electricity consumption savings where respondents were said to be more motivated to save electricity when receiving normative messages than informative messages (Nolan et al., 2008)

\section{Optimistic Bias During New Norms}

The first optimistic bias was detected based on Weinstein's (1980) study in which college students believed that the chances of them experiencing negative events in the future such as divorce were lower and the chances of them experiencing positive events such as owning a home were higher. Optimism is a cognitive process that takes place in the mind that impacts a person's emotions and behaviour (Rashid, 2021). The term biased optimism or unrealistic optimism, unrealistic optimism is the unfounded belief of individuals that they will not experience negative events in the future. Humans tend to predict positive things will happen to themselves in the future excessively and vice versa (Sharot, 2011). For example, individuals believe their risk of becoming a victim of crime is low (Chapin \& Coleman, 2009) and smokers believe that they are less at risk of developing lung cancer than other smokers (Dillhard, McCaul, \& Klein, 2006). According to Sharot (2011), optimistic bias is part of human nature and can be observed at all ages, genders, races and nationalities.

Although optimism bias can promote psychological well-being in general (Taylor and Brown, 1988), there is evidence that at the same time it prevents health promotion behaviour's for at-risk individuals (Dillard, McCaul, \& Klein, 2006). This phenomenon may explain why some individuals tend to disobey SOPs because of the belief that they themselves are unlikely to be infected with the virus. It is similar to the findings of a study reported by Kim \& Niederdeppe (2013), where individuals who have an optimistic bias in avoiding H1N1 virus infection tend not to wash and use hand sanitizer. Rare occurrences such as floods and hurricanes tend to lead to optimism bias because most people believe that they will not be affected by rare events (Shepperd, Waters, Weinstein, \& William, 2015). The same goes for the COVID-19 pandemic that has just strike the world.

Optimism bias is difficult to eliminate or reduce for normal individuals. In fact, a recent study conducted in Poland found that the phenomenon of optimism bias occurred during the COVID-19 pandemic among male and female study subjects where they were confident that they would not be infected with the virus (Dolinski et al., 2020). In addition, there are studies that have been conducted found that media reports that often raise the theme of severity in reporting a pandemic do not have an effect due to the phenomenon of optimistic bias ( $\mathrm{Ha} \&$ Rim, 2020).

However, optimism bias can be reduced when individuals make comparisons with people who are close and known to them, such as family members or friends (Joshi \& Carter, 2013). Therefore, one of the ways to reduce this optimism bias in the context of the COVID- 
19 pandemic is that individuals can make comparisons with those who are close and have been infected with the virus. Individuals are also said to be less optimistic (optimism bias) towards something that is seen to be beyond their control (Klein \& Helweg-Larsen, 2002). For example, individuals tend not to have an optimism bias against the possibility of reexperiencing negative events if they have experienced it before (Helweg-Larsen \& Shepperd, 2001). This is likely to happen to those who have been infected with the COVID-19 virus where they have less optimism (optimism bias) about the possibility of them being re-infected.

Diffusion of Responsibilities During New Norms

The spread of responsibility or diffusion of responsibility began to be studied after the tragedy of Catherine Susan Genovese or Kitty Genovese who was stabbed, raped and finally killed in front of her house in Queens, New York. Surprisingly, it is said that there were 38 witnesses who claimed to have heard the victim's screams, but no one was present to offer help. This incident became the new history of the study of social psychology to find out why humans behave in such a way. Diffusion of responsibility is a phenomenon in which individuals take less action or responsibility when in large groups (Beyer, Bonicalzi, \& Haggard, 2017). The phenomenon often associated with the diffusion of responsibility is the observer effect or bystander effect. The effect of the observer suggests that the more the number of people that are available, there will be lesser individuals who will help a person who is in distress. Following that, Darley \& Latane introduced five steps in the Help Model or model of helping (Latane \& Darley, 1969) that is demonstrated in Figure 4.

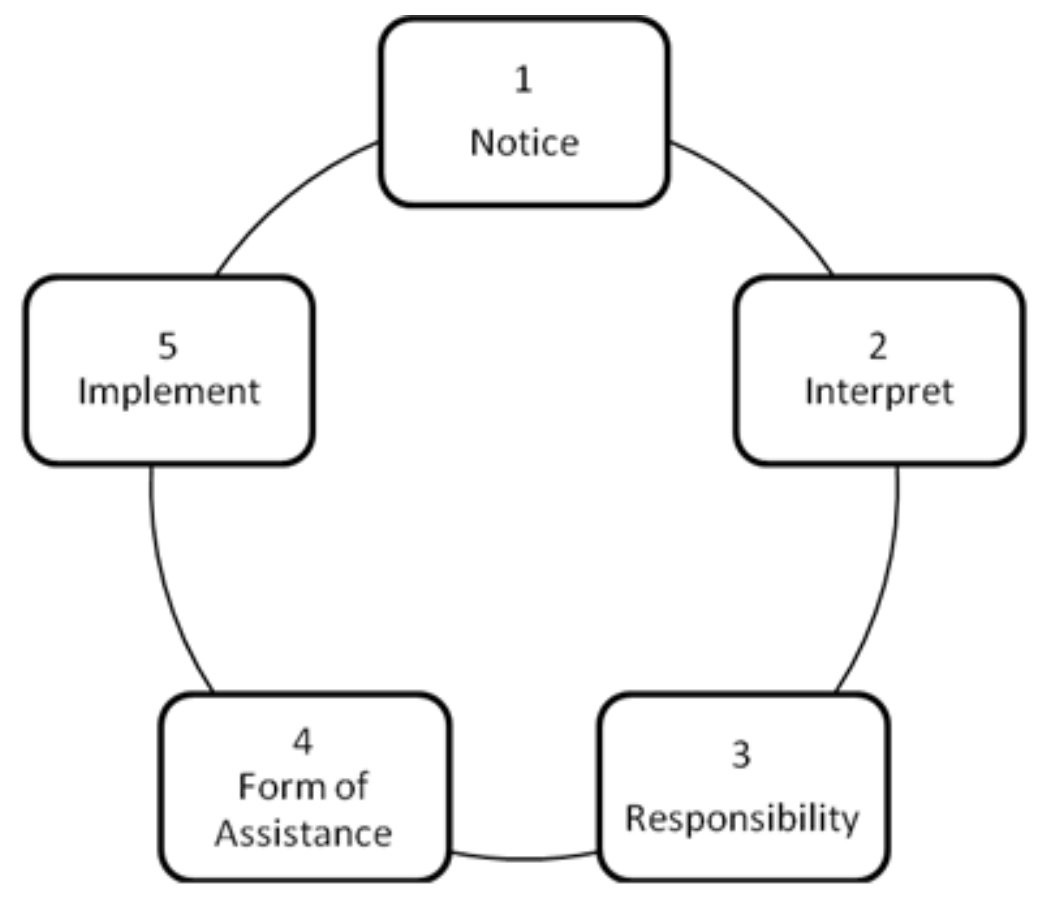

Figure 4: Model of Helping

Based on the Figure 4, an individual is said to go through five steps in this Model of Helping before providing any assistance. The first step is Notice that the individual is aware of the occurrence of the problem. The second step is to Interpret that the individual has to decide what is seen as an emergency. The third step is Responsibility where the individual chooses to act and is willing to take personal responsibility, while the fourth step is the Form 
of assistance i.e. the individual chooses what to do. The last step, the fifth, is Implementation where eventually the individual as an observer will take action. However, the third step is the most critical because individuals who are aware of the problem and offer help when required, yet, do not do so because they think other individuals will help the person in need. According to Tignor \& Colvin (2017), individuals act in such a way as to reduce the psychological effects of shame and guilt if they do not help. They project that there is someone else that will be taking care of the issue. This is because, in the presence of a large crowd, it is easy for individuals to place that responsibility on others.

Malaysians demonstrate diffusion of responsibility during the current pandemic situation. While some people do not comply with the SOP because they think there are others who will comply. They also felt that it would not be a problem for the community if they did not adhere to the SOP because they felt that their contribution did not have a significant impact on efforts to stop the spread of the COVID-19 pandemic. This is due to the lack of emphasis on the element of concern and common interest. Therefore, they feel that there are other individuals who are more authoritative and responsible in curbing the spread of pandemic as they can rely on health workers and security forces.

Therefore, there are several ways that can be done to reduce the impact of the diffusion of responsibility. It should start from the individual level in that the individual needs to instil a sense of responsibility and empathy in themselves without thinking that it is the responsibility of others (diffusion of responsibility). Empathy is putting oneself in the situation of others. Whenever the desire to violate the SOP during COVID-19 appears, individuals need to imagine if they themselves are infected with the virus and are at risk of death or if the virus infects a loved one. In life, everyone has their own moral beliefs and sometimes they are challenged by the surrounding environment. However, everyone should always be reminded with the words that "something wrong is still wrong even though many do it, and something right is still right even if only one person does it". Even campaigns such as \#kitajagakita (\#wecareeachother) and the theme of Malaysia Prihatin (Malaysia Care) national day became a platform to evoke a sense of responsibility in everyone to safeguard common interests during the COVID-19 outbreak.

Sword \& Zimbardo (2015) state that the diffusion of responsibility occurs in large groups. Therefore, in the event of an emergency, individuals should continue to seek help from specific people (directly). With this, the impact of the diffusion of responsibility can be reduced due to the demand for individuals. For example, in the context of this pandemic, when we see that there are individuals who do not comply with the SOP such as not wearing face masks and committing social imprisonment, they need to be given appropriate reprimands in a prudent manner. Extend help if there are individuals in need. For example, individuals who do not wear face masks because they do not have them should be assisted by supplying face masks to them.

\section{Conclusion}

This study set out to explore the compliance behaviour among Malaysians during COVID-19 pandemic from the social psychological point of view. This study has formulated five themes that are relevant to the objective of the paper. These themes are i) social norms during the COVID-19 outbreak, (ii) compliance with new norms through social restrictions, (iii) 
social conformity to adhere to new norms, (iv) optimistic bias during new norms and (v) diffusion of responsibilities during new norms. These findings' themes suggest that in general Malaysians need to have the attitude in that it is everyone business when it comes to following the SOP to curb the pandemic of COVID-19. It seems easy to say than done when one is asked to follow $3 \mathrm{~W}-$ Wash, Wear and Warn. Nevertheless, the $3 \mathrm{~W}$ is now a way of life where one is required to frequently perform handwashing with water and soap (Wash), wear a half-face mask in public places (Wear), and obey warnings from the Ministry of Health $(\mathrm{MOH})$ that is disseminated in the form of warning concept (Warn). In fact, with due understanding of behaviour compliance from social psychology perspectives, it can help to build society awareness in preventing the spread of COVID-19 infection.

\section{Acknowledgement}

We thank to Universiti Sains Islam Malaysia for funding a research grant entitled "Factors Influencing Psychological Well-Being on Stress during the Covid-19 Outbreak" (PPPI / COVID19_0120 / FKP / 051000/13820).

\section{Corresponding Author}

Abdul Rashid bin Abdul Aziz

Faculty of Leadership and Management Universiti Sains Islam Malaysia, 71800, Bandar Baru Nilai, Negeri Sembilan, Malaysia

Email: rashid@usim.edu.my

\section{References}

Aarts, H., Dijksterhuis, A. (2003). The silence of the library: Environment, situational norm and social behavior. Journal of Personality and Social Psychology, 84(1), 18-28. https://doi.org/10.1037/0022-3514.84.1.18

Aziz, A. R. A. (2021). PKP 2.0: Magnet Optimis Memacu Kesejahteraan Diri. Retrieved on Feb $1^{\text {st }}, 2021$ from http://fkp.usim.edu.my/pkp-2-0-magnet-optimis-memacukesejahteraan-diri/

Aziz, A. R. A. (2020). Wabak Covid-19: Penyesuaian Kendiri Terhadap Norma Baharu. Retrieved Sept 15, 2020 from http://fkp.usim.edu.my/wabak-covid-19-penyesuaiankendiri-terhadap-norma-baharu/

Aziz, A. R. A., Sukor, N. M., \& Razak, N. A. (2020). Wabak Covid-19: Pengurusan Aspek Kesihatan Mental Semasa Norma Baharu. International Journal of Social Science Research, 2(4), 156-174

Alexander, J. M. C. K. (2005). The Evolutionary Foundations of Strong Reciprocity. Analyse \& Kritik, 27(1), 106-112. https://doi.org/10.1515/auk-2005-0106

Hamid, A. A. (2020). Wanita jangkitan tempatan pertama koronavirus. My Metro. Accessed on Aug 7, 2020 from:

https://www.hmetro.com.my/utama/2020/02/541989/wanita-jangkitan-tempatanpertama-koronavirus

Aronson, E., Wilson, T. D., \& Akert, A. M. (2005). Social Psychology (5th ed.). Upper Saddle River, NJ: Prentice Hall.

Asch, S. E. (1956). Studies of independence and conformity. A minority of one against a unanimous majority. Psychological Monographs: General and Applied, 70(9), 170. https://doi.org/10.1037/h0093718 
Bernama. (2020). Kronologi COVID-19 di Malaysia sehingga 16 Mac 2020. Retrieved April 4, 2020 from: https://www.bernama.com/bm/am/news_covid-19.php?id=1821899

Bernama. (2020). COVID-19: Sikap rakyat Malaysia tentukan lanjutan PKP. Retrieved Oct 25, 2020 from: https://www.astroawani.com/berita-malaysia/covid19-sikap-rakyatmalaysia-tentukan-lanjutan-pkp-235879

Beyer, F., Sidarus, N., Bonicalzi, S., \& Haggard, P. (2017). Beyond self-serving bias: diffusion of responsibility reduces sense of agency and outcome monitoring. Social Cognitive and Affective Neuroscience. 12(1), 138-145. https://doi.org/10.1093/scan/nsw160

Bond, R., \& Smith, P. B. (1996). Culture and conformity : A meta-analysis of studied using Asch's (1952b.1956) line judgement task. Psychological Bulletin, 119(1), 111-137. https://doi.org/10.1037/0033-2909.119.1.111

Bottoms, A. (2001). Compliance with Community Penalties, in Bottoms, A., Gelsthorpe, L., Rex, S. Community Penalties: Change and Challenges. Cullompton: Willan.

Brandon, A., List, J. A., Metcalfe, R. D., Price, M. K., \& Rundhammer, F. (2019). Testing for crowd out in social nudges: Evidence from a natural field experiment in the market for electricity. PNAS Proceedings of the National Academy of Sciences of the United States of America, 116(12), 5293-5298. https://doi.org/10.1073/pnas.1802874115

Chapin, J., \& Coleman, G. (2009). Optimistic bias: what you think, what you know, or whom you know? North American Journal of Psychology, 11(1), 121-132.

Cialdini, R. B. (2009). Influnece, Science and Practice. (5 ${ }^{\text {th }}$ Edition), Pearson HE, Inc..Kindle Edition.

Cialdini, R. B., \& Goldstein, N.J. (2004). Social influence : Compliance and Conformity. Annual Review of Psychology. 55. 591-621. https://doi.org/10.1146/annurev.psych.55.090902.142015

Cialdini, R. B. (2001). Harnessing the science of persuasion. Harvard Business Review, 79(9), 72-79.

Cialdini, R. B., Reno, R. R., \& Kallren, C. A. (1990). A focus theory of normative conduct. Recycling the concept of norm to reduce littering in public places. Journal of personality and social psychology, 58 ,1015-1026. doi: 10.1037/0022-3514.58.6.1015.

Clark, C., Davila, A., Regis, M., \& Kraus, S. (2020). Predictors of COVID-19voluntary compliance behaviors: An international investigation. Elsevier Public Health Emergency Collection, 2, 76-82. https://doi.org/10.1016/j.glt.2020.06.003

Darley J. M., \& Latané, B. (1968). Bystander Intervention in Emergencies: Diffusion of Responsibility. Journal of Personality and Social Psychology, 8(4), 377-383. doi:10.1037/h0025589

Dillard, A. J., McCaul, K. D., \& Klein, W. M. P. (2006). Unrealistic optimism in smokers: Implications for smoking myth endorsement and self-protetive motivation. Journal of health communication. 11(1), 93-102. https://doi.org/10.1080/10810730600637343

Dolinski, D., Dolinska, B., Zmaczynska-Witek, B., Banach, M., \& Kulesza, W. (2020). Unrealistic Optimism in the Time of Coronavirus Pandemic: May It Help to Kill, If So-Whom: Disease or the Person?. Journal of clinical medicine, 9(5), 1464. https://doi.org/10.3390/jcm9051464

Basaruddin, F. (2020). Dar Al-Hikmah Library: COVID-19 Research Update and Support for Remote Learning. News. International Islamic University Malaysia. Retrieved May 8, 2020 from: http://www.iium.edu.my/my/news/covid-19-research-update-andsupport-for-remote-learning

Festinger, L., Schachter, S., \& Back, K. (1950). Social pressures in informal groups. NY: Harper. 
Ha, J., \& Rim, H. (2020). Does audience optimism transcend the severity of news frame during health pandemic outbreaks? Journal of Communication Science, 20(1), 191-229. doi:10.14696/jcs.2020.03.20.1.191

Hardin, C., \& Higgins, T. (1996). Shared reality: How social verification makes the subject objective. In R.M. Sorrentino \& E.T Highhind (Eds), Handbook of motivation and cognition: Foundaton of social behaviour. (Vol.3, pp. 28-84). NY: Guilford.

Helweg-Larsen, M., \& Shepperd, J. A. (2001). Do moderators of the optimistic bias affect personal or target risk estimates? A review of the literature. Personality and Social Psychology Review, 5, 74-95. https://doi.org/10.1207/S15327957PSPR0501_5

Ismail, I., \& Rahim, R. N. R. (2020). 50 peratus rakyat pulang dari luar negara tak patuh SOP. BH Online. Accessed 21 August 2020 from:

https://www.hmetro.com.my/mutakhir/2020/07/603083/50-peratus-rakyat-pulangdari-luar-negara-tak-patuh-sop

Jonathan, J., Ben, B., Mike, H., Andy, M., Paul, Q., \& Tom, R. T. (2012). Why do People Comply with the Law? Legitimacy and the Influence of Legal Institutions, The British Journal of Criminology, 52(6), 1051-1071.

Jones, L. M., \& Foshay, N. N. (1984). Diffusion of responsibility in a nonemergency situation: Response to a greeting from a stranger. The Journal of Social Psychology, 123(2), 155158.

Joshi, M. S., Carter, W. (2013). Unrealistic optimism: east and west? Front Psychology, 4(6). https://doi.org/10.3389/fpsyg.2013.00006

Kelman, H. C. (1958). Compliance, Identification, and Internalization: Three Processes of Attitude Change. Journal of Conflict Resolution, 2(1). 51-60. https://doi.org/10.1177/002200275800200106

Kim, H. K., \& Niederdeppe, J. (2013). Exploring optimistic bias and the integrative model of behavioral prediction in the context of a campus influenza outbreak. Journal of Health Communication, 18, 206-222. https://doi.org/10.1080/10810730.2012.688247

Kincaid, D. L. (2004). From innovation to social norms : Bounded normative influence. Journal of Health Communication, 9, 37-57. https://doi.org/10.1080/10810730490271511

Klein, C. T. F., \& Helweg-Larsen, M. (2002). Perceived control and the optimistic bias: A metaanalytic review. Psychology \& Health, 17, 437-446. https://doi.org/10.1080/0887044022000004920

Kruglanski, A., \& Stroebe, W. (2011). Handbook of The History of Social Psychology. Philadelphia, PA: Psychology Press.

Latane, B., \& Darley, J.M. (1969). Bystander "Apathy". American Scientist. 57(2). 244-268. https://www.jstor.org/stable/27828530

Loh, I. (2020). Wuhan virus: Eight in isolation in JB after coming into contact with Singapore victim. The Star. Retrieved Feb 17, 2020 from: https://www.thestar.com.my/news/nation/2020/01/24/wuhan-virus-eight-inisolation-in-jb-after-coming-into-contact-with-singapore-victim

McDonald, R. I., \& Crandall, C. S. (2015). Social norms and social influence. Current Opinion in Behavioural Science, 3,147-151. https://doi.org/10.1016/j.cobeha.2015.04.006

Hifzuddin, M. (2020). Kluster Sivagangga : Pemilik kedai nasi kandar didenda, penjara. My Metro. Accessed Aug 17, 2020 from:

https://www.hmetro.com.my/utama/2020/08/609839/kluster-sivagangga-pemilikkedai-nasi-kandar-didenda-penjara-metrotv 
Idris, R. (2020). Reaksi berbeza cadangan naikkan kompaun RM10,000. BH Online. Accessed Sept 3, 2020 from:

http://www.bhplus.com.my/berita/nasional/2020/08/724932/reaksi-berbezacadangan-naikkan-kompaun-rm10000

Miltenberger, R. G. (2012). Behavior Modification: Principles and Procedures, ( $5^{\text {th }}$ ed.). United States Of America: Wadsworth. Wadsworth Cengage Learning.

Rakyat, M. (2020). Lebih 14,000 langgar PKP, 5,930 pesalah sudah dituduh di mahkamah. MindaRakyat.Net. Accessed Oct 25, 2020 from:

https://www.mindarakyat.net/2020/04/lebih-14000-langgar-pkp-5930-pesalah.html

Abdullah, N. H. (2020)., Tingkatkan amalan 3W, jauhi 3S, 3C, Berita Harian Online, Retrieved Oct 15, 2020 from:

https://www.bharian.com.my/berita/nasional/2020/05/693790/tingkatkan-amalan$3 w-j a u h i-3 s-3 c$

Rendsvig, R. K. (2014). Pluralistic ignorance in the bystander effect: informational dynamics of unresponsive witnesses in situations calling for intervention. Synthese. 191.24712498. https://www.jstor.org/stable/24019973

Robinson G., McNeill F. (2008). Exploring the Dynamics of Compliance with Community Penalties. Theoretical Criminology, 12, 431-449.

Robinson, P. H., Darley, J. M. (2004). Does Criminal Law Deter? A Behavioural Science Investigation. Oxford Journal of Legal Studies, 24, 173- 205.

Rothman, A. J., Klein, W. M., \& Weinstein, N. D. (1996). Absolute and relative biases in estimations of personal risk. Journal of Applied Social Psychology, 26, 1213-1236. https://doi.org/10.1111/j.1559-1816.1996.tb01778.x

Sharot, T. (2011). The Optimism Bias. Current Biology, 21(23), R941-R945.

Shepperd, J. A., Klein, W. M. P., Waters, E. A., \& Weinstein, N. D. (2013). Taking stock of unrealistic optimism. Perspectives on Psychological Science, 8, 395-411. https://doi.org/10.1177/1745691613485247

Sherif, M. (1936). The psychology of social norms. NewYork: Harper

Sipalan J., Holmes S. (2020). Malaysia confirms first cases of coronavirus infection. Reuters. Retrieved Mac 11, 2020 from:

https://www.reuters.com/article/china-health-malaysia/malaysia-confirms-firstcases-of-coronavirus-infection-idUSL4N29U03A

Sukumaran, T. (2020). Coronavirus: Malaysia in partial lockdown from March 18

to limit outbreak. South China Morning Post. Retrieved Mac 27, 2020 from: https://www.scmp.com/week-asia/health-

environment/article/3075456/coronavirus-malaysias-prime-minister-muhyiddinyassin

Sword, R., \& Zimbardo, P. (2015). The Bystander Effect. Accessed August

21, 2020 from: https://www.psychologytoday.com/us/blog/the-timecure/201502/the-bystander-effect

Taylor, S. E., \& Brown, J. D. (1988). Illusion and well-being: a social psychological perspective on mental health. Psychology Bulletin. 103, 193-210. doi: 10.1037/00332909.103.2.193

Tignor, S. M., \& Colvin, C. R. (2017). The Interpersonal Adaptiveness of Dispositional Guilt and Shame: A Meta-Analytic Investigation. Journal of Personality, 85(3), https://doi.org/10.1111/jopy.12244

Turner, J. C. (1991). Social Influence. Pacific Grove, CA: Brooks Cole. 
INTERNATIONAL JOURNAL OF ACADEMIC RESEARCH IN BUSINESS AND SOCIAL SCIENCES Vol. 11, No. 7, 2021, E-ISSN: 2222-6990 @ 2021 HRMARS

Tyler, T. R. (2006). Psychological Perspectives on Legitimacy and Legitimation. Annual Review of Psychology, 57, 375- 400.

Zahari, B. J. (2020). Air mata 'makcik gelang pink'. BH Online. Accessed on Aug 18, 2020 from: https://www.bharian.com.my/berita/kes/2020/08/721218/air-mata-makcik-gelangpink 